Stream: Culture/Politics/Technology, 6(1): 9-11

http://journals.sfu.ca/cpt/index.php/stream/index

\title{
The CRTC's Market-driven De-regulation of Canadian television
}

\section{Zoë Druick}

School of Communication, Simon Fraser University

Over the past twenty years, the Canadian television landscape has come to increasingly resemble the market-driven television of the United States, the United Kingdom and Australia, to name only the other major English-language industries. Sports, reality TV, and sci-fi drama dominate, and the public elements of the system are increasingly under siege. How did this happen? A look back over the decisions of the past two decades makes it apparent that Canada's regulatory agency the CRTC has repeatedly enabled the system we now see. These changes are the direct result of NAFTA (the North American Free Trade Deal, signed in 1994), which drastically altered the cultural industries in Canada and led to an entrepreneurial approach to television. Since then, there has been a concerted shift toward an export-oriented industry, provoking a new emphasis on the global trade of cultural products (Edwardson 2008). In effect, even before the impact of the Internet, as the cable dial expanded, and sponsorship was diluted, production costs were pushed down and new, cheaper formats were created. At the same time, ownership became more consolidated and the telecommunication industry merged with the broadcast industry hoping to cash in on the promises of digital and wireless technologies. The CRTC enabled these shifts with the stated intention of increasing Canadian television's competitiveness at an international level (CRTC 1999).

Traditionally, the Canadian content regulations were observed according to the letter of the law. If a broadcaster was compelled to air Canadian content to a minimum of $60 \%$ of the broadcast year and $50 \%$ of the $6 \mathrm{pm}$ to midnight slot, there were numerous ways to avoid airing it in prime time; in other words, viewership was irrelevant to the hours logged. This gave a certain freedom to producers who were often given large amount of latitude in crafting their productions (Edwardson 2008). The 1999 shift (implemented in 2000) saw a new emphasis on showcasing Canadian content in prime time and a laser focus on reaching the large audiences that had rarely been achieved by Canadian productions.

The CRTC also aimed to produce large media companies capable of monetizing their productions in the international marketplace. In 1999 their report stated:

The broadcasting industry has been restructuring through ownership consolidation. This has resulted in efficiencies and synergies that should provide increased investment in Canadian programming and a greater likelihood of the export of that programming. The Commission expects that the consolidation of broadcasting, production and communications companies will continue, to the benefit of Canadian audiences, the Canadian broadcasting system and the public interest (CRTC 1999).

A direct result of this mandate was to undertake renewal hearings for broadcast licenses held by corporations in a group. A little over a decade later when this policy was formalized (July 2011) it had quite a specific effect on programming. In this decision the CRTC allowed large ownership groups not only to have a single licensing hearing, but also to spread their required expenditures on Canadian content across their holdings. This so-called group licensing policy currently allows large media companies to lower the percentage of Canadian content they air from $60 \%$ to $55 \%$. It also makes provision for "flexible" accounting, allowing conglomerates to count expenditures made on one service against the programming expenditure requirements of another. In this way, large broadcasting corporations can buy lucrative American TV or international formats for their conventional channels and make cheaper programming for their specialty channels but count their expenditures as an aggregate across holdings. 
And, since this shift, broadcasters have indeed changed tack. Where for decades, Canadian broadcasters expected to lose money on their Canadian productions, increasingly, the new managerial approach insists on monetizing all content with advertising dollars. This has meant that there is less lea way for Canadian producers; broadcasters have taken more control over the content they are broadcasting, aiming for larger viewing numbers. According to the Canadian Media Concentration Research Project results from 2012, the three biggest telecommunications companies in Canada-Bell, Rogers and Shaw-now account for 75\% of all broadcast in English-Canada and 70\% of all media industry profits in Canada.

A side effect of this approach has been that Canadian owned production companies have begun to imagine themselves operating in a global marketplace as well. If they obtain a contract with a Canadian broadcaster, they will be able to access the Canadian tax credits meant to support Canadian content production, but this is just a stepping-stone. Subsequently they will be able to market their show (to which they maintain the rights) to foreign broadcasters. One direct result of this policy has been a tendency to de-emphasize cultural specificity in shows for ease of international distribution: reality television and science fiction have unsurprisingly been the most successful formats (Baltruschat 2010). It is no wonder that this policy to reduce the obligations of broadcasters to independent producers was opposed by numerous groups in Canada, such as the Canadian Media Production Association, the Documentary Organization of Canada, the Canadian Association of Film Distributors and Exporters and Ontario Media Development Corporation, all of whom saw clearly that it would allow broadcasters to cut back the amount of material produced by independent producers. But rather than heed these calls, the CRTC has worked steadfastly with broadcasters and producers who are striving to create brandable formats that can be sold abroad, such as Recipe to Riches and Love it or List it.

In sum, far from introducing a counterbalance to the deregulation of the Canadian media landscape, since the late 1990s, the CRTC has been facilitating what the agency terms "the entrepreneurial approach" to Canadian television. As happens in many other capitalist markets, entrepreneurialism is in turn subordinated to the timid and conservative profit-making conventions of large media conglomerates. In Canada's case, the take-over of broadcasting by the telecommunications industry has led to the preponderance of low-budget reality programming (with the occasional high budget format show), extensive coverage of professional sports, and a smattering of futuristic sci-fi dramas. Foreign-produced dramatic series remain the mainstay of Canadian primetime. Since these changes have been enabled by the national regulator, perhaps the deregulation of the Canadian media since the mid-1990s should be more accurately be termed "market driven re-regulation".

\section{References}

Baltruschat, Doris (2010) Global Media Ecologies: Networked Production in Film and Television. New York: Routledge.

Canadian Media Concentration Research Project (2014, Jun 2) Retrieved from http://www.cmcrp.org/\#

CRTC (1999, 11 June) Building on success - A policy framework for Canadian television (1999-97). Retrieved from: http://www.crtc.gc.ca/eng/archive/1999/pb99-97.htm.

CRTC (2011, 27 July) Group-based licence renewals for English-language television groups - Introductory decision (2011-441). Retrieved from: http://www.crtc.gc.ca/eng/archive/1999/pb9997.htm.

Edwardson, Ryan (2008). Canadian Content: Culture and the Quest for Nationhood. Toronto: University of Toronto Press. 


\section{About the Author}

Zoë Druick is Associate Professor in the School of Communication. Her primary areas of teaching and research are media studies, cultural industries and cultural theory. Her research considers histories, theories and trajectories of documentary and reality-based media. Her most recent books are The Grierson Effect: Tracing Documentary's International Movement (BFI 2014, with Deane Williams) and Cinephemera: Archives, Ephemeral Cinema and New Screen Histories in Canada (McGillQueen's University Press 2014, with Gerda Cammaer). 